\title{
A nátrium-glükóz-kotranszporter-2-gátlók a diabetes mellitus kezelésén túl
}

\author{
Szekeres Zsolt János, Stolcz Tünde, Szabados Eszter
}

\author{
Pécsi Tudományegyetem, Általános Orvostudományi Kar, I. sz. Belgyógyászati Klinika, Kardiológiai Prevenciós \\ és Rehabilitációs Tanszék, Pécs
}

Levelezési cím: Dr. Szabados Eszter

Pécsi Tudományegyetem, Általános Orvostudományi Kar. 1. sz. Belgyógyászati Klinika, Kardiológiai Prevenciós és Rehabilitációs Tanszék, 7623 Pécs, Rákóczi út 2. E-mail: szabados.eszter@pte.hu

A nátrium-glükóz-kotranszporter-2-gátlók mára a 2-es típusú diabetes mellitus gyógyszeres terápiájának egyik meghatározó elemévé váltak. Számos klinikai tanulmány igazolta ezen hatóanyagok pozitív hatását a kardiovaszkuláris mortalitás és morbiditás csökkentésében, így például az EMPA-REG OUTCOME az empagliflozin, a CANVAS, CANVAS-R-vizsgálatok a canagliflozin és a DECLARE-TIMI 58 a dapagliflozin esetében. Ezen kardioprotektív hatások magyarázatára számos hipotézis született. A szénhidrát-anyagcserére való hatásain túl a szervezet számos más részére is hatással vannak. Jelen összefoglaló közleményünkben a nátrium-glükóz-kotranszporter-2-gátlók főbb, szisztémás hatásait kívánjuk bemutatni.

Kulcsszavak: diabetes mellitus, kardiovaszkuláris protekció, farmakodinámia

\section{Sodium-glucose cotransporter 2 inhibitors - beyond the treatment of diabetes mellitus}

Sodium-glucose co-transporter 2 inhibitors have become one of the determinants of drug therapy for type 2 diabetes. Several clinical studies have demonstrated their positive effect in reducing cardiovascular mortality and morbidity, such as EMPA-REG OUTCOME for empagliflozin, CANVAS, CANVAS-R for canagliflozin, and DECLARE-TIMI 58 for dapagliflozin. Several hypotheses have been created to explain these cardioprotective effects. In addition to their effects on carbohydrate metabolism, they also affect many other parts of the body. In this review, we aim to present the main systemic effects of sodium glucose cotransporter 2 inhibitors.

Keywords: diabetes mellitus, cardiovascular protection, pharmacodynamics

\section{Bevezetés}

Jelenleg 6 humán SGLT (sodium-glucose co-transporter) proteint azonosítottak, amik közül az SGLT1- és SGLT2-receptorokat kutatták alaposabban az elmúlt években. Az SGLT1 és SGLT2 közötti kimagasló szekvenciahomológia ellenére eltérő élettani és biokémiai tulajdonságokat mutatnak. Míg az SGLT1 primeren a belekben expresszálódik, addig az SGLT2 legnagyobb mértékben, a vesekéregben, ahol fontos szerepet játszik a vese glükóz-reabszorpciójában. Az SGLT1 ma- jor szubsztrátjai a glükóz és a galaktóz, míg az SGLT2 erősen szelektív a glükózra. A kötődő nátrium-glükóz sztöchiometrikus aránya 2:1 az SGLT1, és 1:1 az SGLT2 esetén. Az SGLT1 mutációi glükóz-galaktóz malabszorpciókat okoznak, szemben az SGLT2-mutációival, amiket a familiáris renalis glükozuriával hoztak összefüggésbe. Az SGLT2-gátlókat, beleértve a dapagliflozint, canagliflozint, ipragliflozint, tofogliflozint, luseogliflozint és empagliflozint, a 2-es típusú diabetes mellitus kezelésére vizsgálták számos klinikai tanulmány során. $A z$ SGLT2-receptor iránti szelektivitásuk jelentős szórást

A kézirat 2020. 06. 19-én érkezett a szerkesztőségbe, 2020. 08. 28-án került elfogadásra. 
mutat. Míg az empagliflozin 2500x, ertugliflozin 2000x, a dapagliflozin $1200 \times$, addig a canagliflozin $250 \times$, a sotagliflozin csak 20× szelektívebb az SGLT2-receptorra az SGLT1-hez képest, amely a hatásmechanizmusban jelentős eltéréseket okozhat (1). A többi SGLT-receptor pontosabb vizsgálata még kezdeti szakaszban jár. Érdekes módon az SGLT3-nak nincs glükóztranszporter aktivitása, de az enterális idegrendszer neuronjai számára glükózszenzorként szolgálhat. Az SGLT4 nagyobb affinitást mutat mannóz iránt, mint glükózra, és feltehetöleg mannóz-transzporterként funkcionál. Az SGLT5, ami a vesekéregben nagymértékben expreszszálódik, szintén magas mannózaffinitással rendelkezik. Az SGLT6, amit SMIT2-ként (mioinozitol-nátrium szimporter) is ismerünk, glükóz helyett inozitolt transzportál (2).

Számos tanulmány kimutatta az SGLT2-gátlók pozitív hatását a kardiovaszkuláris mortalitás és morbiditás csökkentésében, így például az EMPA-REG OUTCOME (3) az empagliflozin, a CANVAS (4), CANVAS-R (5) vizsgálatok a canagliflozin és a DECLARE-TIMI 58 (6) a dapagliflozin esetében. Ezen kardioprotektív hatások magyarázatára számos hipotézis született. Jelen közleményünkben az SGLT2-gátlók kardioprotektív és szisztémás hatásait kívánjuk összefoglalni (1. ábra).

\section{A diuretikus hipotézis}

Az SGLT2-gátlók fokozzák a natriuresist a proximális renalis tubulusokban, ami ozmotikus diurézishez vezet. A diuretikus hatás mértéke a vércukorszinttől nem teljesen független. Magasabb vércukorszint mellett (pl. diétahiba esetén) nagyobb mértékü hatást észlelhetünk. A volumencsökkenés csökkenti az elöterhelést és a kamra töltőnyomását, ebből következő- leg csökkenti a myocardium feszülését, és a kamrai aritmiák kialakulásának rizikóját $(7,8)$. Az EMPA-REG OUTCOME-vizsgálat eredményei alapján a hematokrit és a hemoglobin növekedése voltak a legfontosabb mediátorok a kardiovaszkuláris rizikó csökkentésében (9). Ez a növekedés a hematokrit értékében lehetséges, hogy az SGLT2-gátlás okozta ozmotikus diurézisből következő plazmatérfogat-csökkenésnek köszönhetö, de ezen gyógyszerek erythropoesisre való pozitív hatása is felmerült (10). Ezen felül az előterhelés csökkenése részben megmagyarázhatja a bal kamra tömegének csökkenését is (11). Ugyanakkor fontos megemlíteni azt is, hogy ezek a hatások különböznek a diuretikumok más fajtáinak hatásaitól, hiszen az SGLT2-gátlók nem okoznak kompenzatorikus szimpatikus aktivációt, ioneltéréseket, mint pl. a hypokalaemia vagy hypomagnesaemia, nemkívánatos metabolikus hatásokat, mint pl. a hyperurikaemia, sem nemkívánatos renalis hemodinamikai hatásokat (12-15).

A renalis glükózexkréció további hatása a testsúly csökkenése. Bolinder és munkatársai egy 24 hetes tanulmány keretén belül 2 csoportot vizsgáltak. Míg az egyik csoport metformin (1500-2000 mg/nap és placebokezelésben részesültek, addig a másik csoport metformint és dapagliflozint kapott (10 mg/nap). Az első eredmények alapján a 2. csoportban intenzívebb polyuriát figyeltek meg, valamint a csípökörfogat, és a zsírtömegindex erőteljesebb csökkenését (16). A kalóriavesztés hátterében részben a glükóz fokozott eliminációja, másrészt a következményesen megnövekedett lipidmetabolizmus állhat. Továbbá érdekes összehasonlítani az empagliflozin-monoterápia és a metforminnal való kombinált kezelés során észlelt súlyváltozást: monoterápiában $2,1 \mathrm{~kg}$, míg együttes terápiánál $3,3 \mathrm{~kg}$ volt a súlyvesztés (17).

\section{SGLT2-GÁTLÓK FÖBB HATÁSAI A SZÉNHIDRÁTHÁZTARTÁSRA VALÓ HATÁSOKON TÚL}

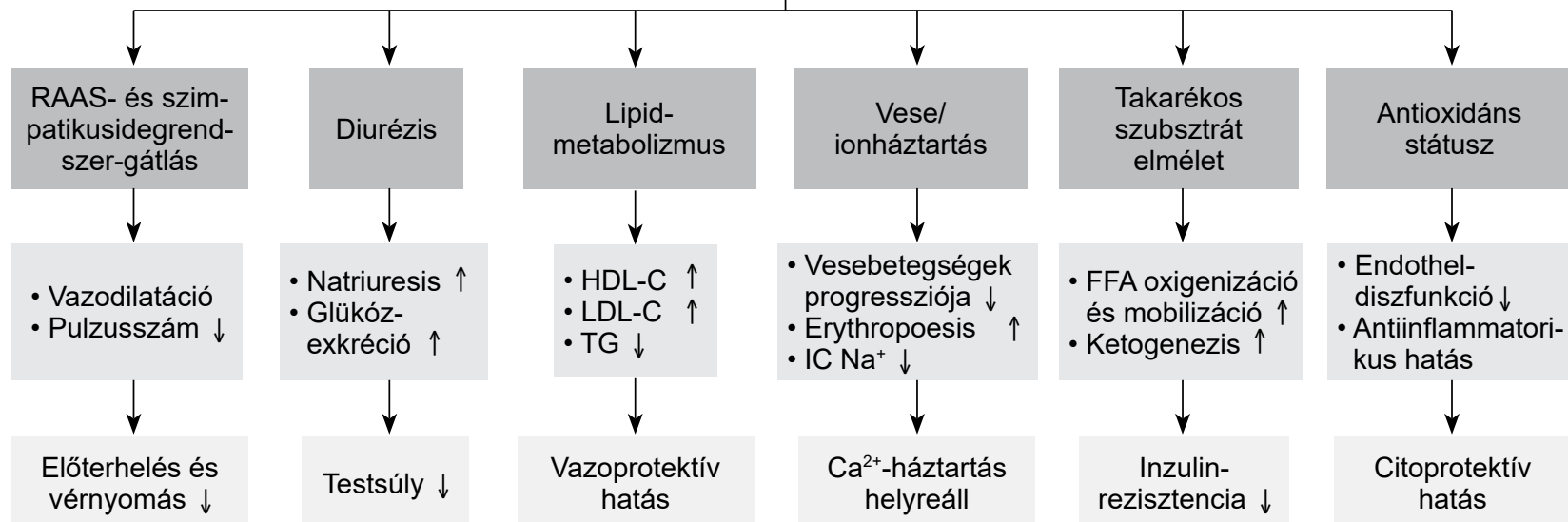

1. ÁBRA. Az SGLT2-gátlók főbb hatásai a szénhidrátháztartásra való hatásokon túl. HDL-C: magas sűrűségű lipoprotein-koleszterin (high-density lipoprotein cholesterol); LDL-C: alacsony sürűségú lipoprotein-koleszterin (low-density lipoprotein cholesterol); TG: trigliceridek; IC: intracelluláris; FFA: szabad zsírsavak (free fatty acids) 


\section{A vérnyomáscsőkkenés hipotézise}

Az SGLT2-gátlók csökkentik mind a szisztolés (SBP), mind a diasztolés vérnyomásértékeket (DBP) körülbelül 4-6 Hgmm-rel a szisztolés, és 1-2 Hgmm-rel a diasztolés értéket illetően a natriurézisnek és ozmotikus diurézisnek, a csökkent artériás merevségnek (a csökkent nátriumkoncentráció miatt), és feltehetőleg a csökkent testsúlynak köszönhetöen (16-18). Egy újabb, 33 randomizált klinikai tanulmányból készült metaanalízis szerint a rendelöben, ülő helyzetben mért szisztolés érték maximum $49 \mathrm{Hgmm}$-rel, a diasztolés érték maximum 2,0 Hgmm-rel csökkent 17 600, 2-es típusú diabetes mellitusban (T2DM) szenvedő betegben SGLT2-gátló kezelés mellett. A vérnyomáscsökkenést az alacsonyabb artériás merevséggel, az utóterhelés csökkenésével magyarázták. Ezen túlmenően a dippingmintázat visszatérése, és csökkenő nátriumretenció is megfigyelhető volt (19). Felmerült a lehetősége annak is, hogy az SGLT2-gátlók a vérnyomás cirkadiánritmusának visszaállitásával rendelkeznek további kardioprotektív hatással (20-25). Érdekes kérdés, hogy az SGLT2-gátlók milyen hatásmechanizmusa állhat a cirkadiánritmus visszaállitása mögött. Egy lehetséges feltételezés szerint a visceralis zsír felhalmozódása rizikófaktora a cirkadiánritmus felborulásának. Így az SGLT2-gátlók a visceralis zsír csökkentésén keresztül hatással lehetnek a cirkadiánritmusra is (7). A vérnyomáscsökkentő hatás azonban legfőképpen antihipertenzív szerekkel való kombinációban volt megfigyelhető (26). A SGLT2- gátlók vérnyomásra kifejtett hatásai részben állhatnak a kardioprotektív hatásuk hátterében, mindazonáltal önmagukban nem magyarázzák a megfigyelt kardiovaszkuláris, és a renalis végpontok csökkenését. Fontos továbbá megemlíteni, hogy a vérnyomáscsökkenést nem követte szignifikáns csökkenés a stroke elöfordulásában sem a CANVAS, sem az EMPA-REG OUTCOME-vizsgálatokban (27).

\section{A „takarékos szubsztrát" elmélet}

A „takarékos szubsztrát” elmélet szerint az SGLT2-gátlók fokozzák a szabad zsírsavak oxidációját, és ez legalább részben, hozzájárul az inzulinrezisztencia és az endothelialis funkció javulásához, részben az oxidatív stressz csökkentésén, részben az eNOS-funkció helyreállitásán keresztül, ami hozzájárul a kardiovaszkuláris betegségek (CVD) rizikójának csökkenéséhez (21). Az SGLT2-gátlás hozzájárul a ketontestek fokozott képzödéséhez a szabad zsírsavak fokozott mobilizációja és oxidációja miatt a májban, ami növeli a glükagon/inzulinarányt, valamint a csökkent glükózszint által csökken az inzulinrezisztencia (28). llyen ketontest például a keletkező béta-hidroxibutirát, amit kisebb mennyiségben a szívizomsejtek és vesesejtek is képesek felhasználni, ezáltal csökkentve a miokardiális szabadzsírsav- (FFA) oxidációt és oxigénfelhasználást, ezáltal mind a vese, mind a szív müködését javítva (29). A ketontest oxidációja energetikailag hatékonyabb, mint a zsírsav-oxidáció, mert magasabb ATP/oxigénarányt eredményez, mint más szubsztrátok (30). Továbbá a béta-hidroxibutirát antioxidáns és antiaritmiás hatásokkal is rendelkezik $(30,31)$. Lehetséges, hogy az SGLT2-gátlók a plazmaglükóz-koncentráció csökkentésén túl a myocardium metabolizmusának a zsírsavak és ketontestek felé való eltolásával is rendelkezik kardioprotektív hatással. Ugyanakkor egyéb antidiabetikus gyógyszerek is kompenzatorikus módon növelhetik a ketontestek képződését, de az SGLT2-gátlók emellett fokozzák a lipolízist is, és korlátozhatják a trigliceridek felhalmozódását a szervekben (32). A „takarékos szubsztrát” elmélet igazolására további vizsgálatokra van szükség, különösen azért is, mert sem az EMPA-REG OUTCOME-, sem a CANVAS-vizsgálatok során nem csökkent szignifikáns mértékben a miokardiális infarktus előfordulása (33).

\section{A metabolikus hatás hipotézise}

A metabolikus hatás hipotézise szerint az ozmotikus diuretikus hatás mellett a metabolikus változások a visceralis zsírmennyiség és a testsúly csökkenéséhez vezetnek SGLT2-gátló kezelés során. Azonban az EMPA-REG OUTCOME- és a CANVAS-vizsgálatok adatai alapján nagyobb mértékủ testsúlycsökkenés nem járt nagyobb mértékü CV-esemény-csökkenéssel (34). SGLT2-gátlók hatására a szérumtriglicerid-szint csökkenését, valamint a HDL-C szintjének emelkedését figyelték meg. Érdekes módon az LDL-C szintje enyhén emelkedhet, feltehetöleg az LDL-receptorok aktivitásának csökkenése miatt (7).

A pozitív metabolikus hatáshoz hozzátartozik továbbá, hogy az SGLT2-gátlók csak ritkán okoznak hypoglykaemiát, amely köztudottan fokozott szimpatikus aktivitáshoz, magasabb pulzusszámhoz és perifériás szisztolés vérnyomáshoz, aritmiahajlamhoz vezethet (35). Fontos további hatásuk az EPO-szint emelése, ami jelentősen növelheti az oxigénellátást, ezáltal javítva a myocardium funkcióját $(14,36)$.

\section{Az SGLT2-gátlók ioncsatornákra kifejtett hatása}

Az újabb eredmények alapján az SGLT2-gátlók fontos szerepet játszanak a diabéteszes szív ionháztartásában, és potenciálisan protektív hatással bírnak mind szisztolés, mind diasztolés szívelégtelenségben. Szívelégtelenségben a szívizomsejtek fokozott intracelluláris nátrium- és kalciumszintet mutatnak, részben a Na-H (NHE) és a Na-Ca (NCX) transzporterek fokozott aktivitása miatt (37). Empagliflozin hatását vizsgálva izolált kamrai szívizomsejteken emelkedett 
extracelluláris glükóz esetén arra az eredményre jutottak, hogy a szívizomsejt citoszol $\mathrm{Na}^{+}$és $\mathrm{Ca}^{2+}$-szintje csökken empagliflozin hatására, míg a mitokondriumok $\mathrm{Ca}^{2+}$-koncentrációja nő (37). Bár SGLT2-receptorok nem expresszálódnak az emberi myocardiumban, az SGLT2-gátlók direkten csökkenthetik az NHE és következményesen az NCX-transzporterek aktivitását az NHE1-en található SGLT2-kötőhelyen keresztül, ami csökkent intracelluláris nátriumszinthez, és helyreállított kalciumháztartáshoz vezet, amelyek végeredményben jobb kontraktilis funkciót, valamint csökkent kamrai aritmia és hirtelen szívhalálrizikót jelenthet (37).

\section{Az SGLT2-gátlók hatása a szimpatikus idegrendszerre}

A szimpatikus idegrendszer túlzott, krónikus aktivitását számos klinikai állapotban igazolták, beleértve az iszkémiás szívbetegséget, a szívelégtelenséget, a hipertóniát, a T2DM-betegséget és a metabolikus szindrómát. A szimpatikus idegrendszer túlzott aktivitása rossz prognózissal társul szívelégtelen és végstádiumú veseelégtelenségben szenvedő betegek esetén. A szimpatikus aktivitás krónikus növekedése nemcsak hipertenzió kialakulásához vezethet, de káros hatással van az erekre és a vesékre is. A szimpatikus túlmüködés fokozza az artériás merevséget, endothelialis diszfunkciót okoz és megváltoztatja a vese nátrium- és vízhomeosztázisát is. A szimpatikus túlmüködés következményeinek epicentruma a vese, az ebböl következő renalis stressz pedig tovább fokozhatja a szimpatikus aktivitást. Metabolikus szindrómás patkánymodellben az SGLT2-gátlás visszaállította a szimpatikus idegrendszer cirkadián ritmusát (38).

\section{Az SGLT2-gátlók hatása krónikus veselbetegségre}

Az EMPA-REG OUTCOME-vizsgálat eredményei alapján az SGLT2-gátló kezelés hatására szignifikánsan csökkent a vesebetegségek progressziója, beleértve a becsült glomeruláris filtrációs ráta (eGFR) csökkenés progresszióját és a vesepótló kezelések indításának szükségességét. Ezen kívül a CANVAS-vizsgálat eredményei is a canagliflozinterápia renalis kimenetelre való pozitív hatását mutatta $(38,39)$. A krónikus vesebetegség előrehaladásával fibrózis lép fel, emiatt az EPO-termelés csökkenhet. Yanagida és társai vizsgálatának (40) eredményei felvetik a lehetőségét annak, hogy az SGLT2 gátlásával csökken a proximális tubuláris sejtek energiaigényes glükózreszorpciója, ami így a csökkent energiafogyasztás miatt a diabetikus vesék strukturális és funkcionális javulásához vezethet, ami lehetővé teszi az EPO termelésének fokozódását, ezáltal a hematokrit növekedését. A kérdésre, miszerint az SGLT2-gátlók pontosan milyen hatással vannak a már kialakult diabéteszes vesebetegségre a CREDENCE-vizsgálat alapján kaphatunk majd választ (41).

\section{Az SGLT2-gátlók hatása az oxidatív stresszre és gyulladásra}

Kísérletes vizsgálatok felvetették az SGLT2-gátlók antiinflammatorikus, antioxidáns és antiproliferatív hatásait, különösen a proximális renalis tubulusokban, azonban további vizsgálatokra van szükség ezen eredmények emberben való fontosságának megállapítására (42). A canaglilfozin az egyik legkevésbé szenzitív az SGLT2-receptorokra az SGLT2-gátlók közül, ami ezáltal nagyobb SGLT1-gátló hatással bír, ami által csökkenti a hyperglykaemia-indukálta reaktív oxigén-szabadgyök termelését a szívben, csökkentve az iszkémiás szívizmot érő oxidatív stressz mértékét (43). 10 hetes empagliflozinkezelésre diabéteszes egerekben szignifikánsan javult a kardiális és a perikoronáriás artériás fibrózis és a makrofáginfiltráció mértéke. Az eredmények azt mutatták, hogy szignifikánsan csökkent a szuperoxid-termelés a szívben, ami az SGLT2-gátlók antioxidáns hatására utalhat (44). Ez a hipotézis megmagyarázhatja az empagliflozin elönyös hatását a szívfunkcióra a szisztémás metabolikus vagy hemodinamikai változások hiányában is, ahogy a hirtelen szívhalál rizikójának szignifikáns csökkenését is, amit az EMPA-REG OUTCOME-vizsgálatban figyeltek meg (45). Fontos megemlíteni az SGLT2-gátlók hatását az érrendszerre. Az ipragliflozinnal kapcsolatos vizsgálatok kimutatták, hogy az endothelialis diszfunkció elleni védő hatása az SGLT2-gátlásnak a gyulladás szabályozásának és az oxidatív stressz csökkentésének köszönhető (46). SGLT2-gátló kezelés hatására csökkent a vaszkuláris inflammatorikus molekulák expreszsziója, mint például a monocita kemoattraktáns protein-1 (MCP-1), az intracelluláris adhéziós molekula (ICAM) és a vaszkuláris sejt adhéziós molekula-1 szintje (VCAM-1) is (47).

\section{Az SGLT2-gátlók mellékhatásai}

Az SGLT2-gátlók számos pozitív hatásának ismertetése után szót kell ejtenünk esetleges mellékhatásaikról is. A leggyakoribb mellékhatások közé tartoznak az urogenitális infekciók, mikózisok, bakteriális infekciók, amelyek hátterében a vizelet emelkedett glükózkoncentrációja áll. Elkerülésükhöz elengedhetetlen a fokozott higiénia betartása, amelyre a betegek figyelmét fel kell hívnunk (48).

A fokozott diurézis felveti a csontsürüség csökkenésének lehetőségét, azonban jelenleg a kutatások ezt nem erősítették meg. Azonban a csonttörések incidenciájának enyhe emelkedését figyelték meg canagliflozinterápia során (48). 
Az euglykaemiás diabéteszes ketoacidózis (DKA) ritka, de súlyos mellékhatása lehet az SGLT2-gátló gyógyszereknek, amit a ketogenezisnek kedvező körülmények között figyeltek meg, mint például fokozott alkoholfogyasztás, volumenvesztés, infekció, stroke és miokardiális infarktus (29). SGLT2-gátló gyógyszeres kezelésben részesülőknél fokozódik a DKA rizikója SARS-CoV-2-infekció esetén is. Ilyenkor az SGLT2-gátlók átmeneti felfüggesztése szükséges, és a ketontestek mérése már a mérsékelten emelkedett vércukorszintek mellett is javasolt (49).

\section{Következtetések}

Összegezve megállapíthatjuk, hogy az SGLT2-gátlók pleiotróp, szisztémás hatással rendelkeznek az emberi szervezetre. Annak eldöntésére, hogy az ismert kardioprotektív hatás melyik hatásmechanizmusnak köszönhető elsősorban, illetve, hogy ezen hatások együttes eredménye-e, további vizsgálatok szükségesek. Mindenesetre a pozitív metabolikus és kardioprotektív hatások önmagukban is tanúsítják az SGLT2-gátlók klinikai felhasználásának fontosságát, a szénhidrát-háztartásra való hatásain túl. A jelenleg is folyó kutatások fognak arra választ adni, hogy a jövőben milyen más indikációkkal tudjuk majd az SGLT2-gátlókat alkalmazni.

\section{Nyilatkozat}

A szerzők kijelentik, hogy az összefoglaló közlemény megírásával kapcsolatban nem áll fenn velük szemben pénzügyi vagy egyéb lényeges összeütközés, összeférhetetlenségi ok, amely befolyásolhatja a közleményben bemutatott eredményeket, az abból levont következtetéseket vagy azok értelmezését.

\section{Irodalom}

1. Cinti F, Moffa S, Impronta F, et al. Spotlight on ertugliflozin and its potential in the treatment of type 2 diabetes: evidence to date. Drug Des Devel Ther 2017; 11: 2905-2919. https://doi.org/10.2147/DDDT.S114932 2. Deng D, Yan N GLUT, SGLT, and SWEET. Structural and mechanistic investigations of the glucose transporters. Protein Sci 2016; 25: 546-558. https://doi.org/10.1002/pro.2858

3. Zinman B, Wanner C, Lachin JM, et al. Empagliflozin, cardiovascular outcomes, and mortality in type 2 diabetes. N Engl J Med 2015; 373: 2117e2128. https://doi.org/10.1056/NEJMoa1504720

4. Bruce N, Vlado Perkovic. Canagliflozin and Cardiovascular and Renal Events in Type 2 Diabetes. N Engl J Med 2017; 377: 644-657. https://doi.org/10.1056/NEJMoa1611925

5. Vlado P, Dick dZ, Kenneth WM, et al. Canagliflozin and renal outcomes in type 2 diabetes: results from the CANVAS Program randomised clinical trials. Lancet Diabetes Endocrinol 2018.

https://doi.org/10.1016/S2213-8587(18)30141-4

6. Wiviott SD, Raz I, Bonaca MP, et al. Dapagliflozin and cardiovascular outcomes in type 2 diabetes. N Engl J Med 2019; 380: 347-357. https://doi.org/10.1056/NEJMoa1812389

7. Filippatos TD, Liontos A, Papakitsou I, et al. SGLT2 inhibitors and cardioprotection: a matter of debate and multiple hypotheses. Post- grad Med 2019; 131: 82-88

https://doi.org/10.1080/00325481.2019.1581971

8. Ferrannini E, Veltkamp SA, Smulders RA, et al. Renal glucose handling: impact of chronic kidney disease and sodium-glucose cotransporter 2 inhibition in patients with type 2 diabetes. Diabetes Care 2013; 36: 1260-1265. https://doi.org/10.2337/dc12-1503

9. Inzucchi SE, Zinman B, Fitchett D, et al. How does empagliflozin reduce cardiovascular mortality? Insights from a mediation analysis of the EMPAREG OUTCOME trial. Diabetes Care 2018; 41: 356-63. https://doi.org/10.2337/dc17-1096

10. Sano M, Takei M, Shiraishi Y, et al. Increased hematocrit during sodiumglucose cotransporter 2 inhibitor therapy indicates recovery of tubulointerstitial function in diabetic kidneys. J Clin Med Res 2016; 8: 844-7. https://doi.org/10.14740/jocmr2760w

11. Verma S, Garg A, Yan AT, et al. Effect of empagliflozin on left ventricular mass and diastolic function in individuals with diabetes: An important clue to the EMPA-REG OUTCOME trial? Diabetes Care 2016; 39: e212-e3. https://doi.org/10.2337/dc16-1312

12. Sano M. A new class of drugs for heart failure: SGLT2 inhibitors reduce sympathetic overactivity. J Cardiol 2018; 71: 471-6.

https://doi.org/10.1016/j.jjcc.2017.12.004

13. Filippatos TD, Tsimihodimos V, Liamis G, et al. SGLT2 inhibitors-induced electrolyte abnormalities: An analysis of the associated mechanisms. Diabetes Metab Syndr 2018; 12: 59-63.

https://doi.org/10.1016/j.dsx.2017.08.003

14. Zhao Y, Xu L, Tian D, et al. Effects of sodium-glucose co-transporter 2 (SGLT2) inhibitors on serum uric acid level: A meta-analysis of randomized controlled trials. Diabetes Obes Metab 2017. https://doi.org/10.1111/dom.13101

15. Tsimihodimos V, Filippatos TD, Filippas-Ntekouan S, et al. Renoprotective effects of SGLT2 inhibitors: Beyond glucose reabsorption inhibition. Curr Vasc Pharmacol 2017; 15: 96-102.

https://doi.org/10.2174/1570161114666161007163426

16. Bolinder J, Ljunggren Ö, Kullberg J, et al. Effects of dapagliflozin on body weight, total fat mass, and regional adipose tissue distribution in patients with type 2 diabetes mellitus with inadequate glycemic control on metformin. The Journal of Clinical Endocrinology \& Metabolism 2012; 97(3): 1020-1031. https://doi.org/10.1210/ jc. $2011-2260$

17. Rosenstock J, Jelaska A, Frappin G, et al. Improved glucose control with weight loss, lower insulin doses, and no increased hypoglycemia with empagliflozin added to titrated multiple daily injections of insulin in obese inadequately controlled type 2 diabetes. Diabetes Care 2014; 37: 1815-23. https://doi.org/10.2337/dc13-3055

18. Ribola FA, Cancado FB, Schoueri JH, et al. Effects of SGLT2 inhibitors on weight loss in patients with type 2 diabetes mellitus. Eur Rev Med Pharmacol Sci 2017; 21: 199-211.

19. Chilton R, Tikkanen I, Cannon CP, et al. Effects of empagliflozin on blood pressure and markers of arterial stiffness and vascular resistance in patients with type 2 diabetes. Diabetes Obes Metab 2015; 17: 1180-93. https://doi.org/10.1111/dom.12572

20. Filippatos TD, Tsimihodimos V, Elisaf MS. Mechanisms of blood pressure reduction with sodium-glucose co-transporter 2 (SGLT2) inhibitors. Expert Opin Pharmacother 2016; 17: 1581-3.

https://doi.org/10.1080/14656566.2016.1201073

21. Rahman A, Hitomi H, Nishiyama A. Cardioprotective effects of SGLT2 inhibitors are possibly associated with normalization of the circadian rhythm of blood pressure. Hypertens Res 2017; 40: 535-40. https://doi.org/10.1038/hr.2016.193

22. Zaccardi F, Webb DR, Htike ZZ, et al. Efficacy and safety of sodium-glucose co-transporter-2 inhibitors in type 2 diabetes mellitus: systematic review and network meta-analysis. Diabetes Obes Metab 2016; 18: 783-794. https://doi.org/10.1111/dom.12670

23. Weber MA, Mansfield TA, Cain VA, et al. Blood pressure and glycaemic effects of dapagliflozin versus placebo in patients with type 
2 diabetes on combination antihypertensive therapy: a randomised, double-blind, placebocontrolled, phase 3 study. Lancet Diabetes Endocrinol 2016; 4: 211-20. https://doi.org/10.1016/S2213-8587(15)00417-9 24. Takeshige $Y$, Fujisawa $Y$, Rahman $A$, et al. A sodium-glucose cotransporter 2 inhibitor empagliflozin prevents abnormality of circadian rhythm of blood pressure in salt-treated obese rats. Hypertens Res 2016; 39: 415-422. https://doi.org/10.1038/hr.2016.2

25. Tamura K, Wakui H, Azushima K, et al. Circadian blood pressure rhythm as a possible key target of SGLT2 inhibitors used for the treatment of Type 2 diabetes. Hypertens Res 2016; 39: 396-398. https://doi.org/10.1038/hr.2016.1

26. Lambers HHJ, de Zeeuw D, Wie L, et al. Dapagliflozin a glucose-regulating drug with diuretic properties in subjects with type 2 diabetes. Diabetes Obes Metab 2013; 15: 853-862. https://doi.org/10.1111/dom.12127 27. Mori H, Okada Y, Kawaguchi M, et al. A case of type 2 diabetes with a change from a non-dipper to a dipper blood pressure pattern by dapagliflozin. J UOEH 2016; 38: 149-153.

https://doi.org/10.7888/juoeh.38.149

28. Xie X, Atkins E, Lv J, et al. Effects of intensive blood pressure lowering on cardiovascular and renal outcomes: updated systematic review and metaanalysis. Lancet 2016; 387: 435-43.

https://doi.org/10.1016/S0140-6736(15)00805-3

29. Merovci A, Solis-Herrera C, Daniele G, et al. Dapagliflozin improves muscle insulin sensitivity but enhances endogenous glucose production. J Clin Invest 2014; 124: 509-14.

https://doi.org/10.1172/JCl70704

30. Fralick M, Schneeweiss S, Patorno E. Risk of diabetic ketoacidosis after initiation of an SGLT2 inhibitor. N Engl J Med 2017; 376 2300-2. https://doi.org/10.1056/NEJMc1701990

31. Ferrannini E, Mark M, Mayoux E. CV protection in the EMPAREG OUTCOME trial: A "Thrifty Substrate" hypothesis. Diabetes Care 2016; 39: 1108-14. https://doi.org/10.2337/dc16-0330

32. Kahl S, Gancheva S, Straßburger K, et al. Empagliflozin Effectively Lowers Liver Fat Content in Well-Controlled Type 2 Diabetes: A Randomized, Double-Blind, Phase 4, Placebo-Controlled Trial. Diabetes Care 2020; 43: 298-305. https://doi.org/10.2337/dc19-0641 33. Shimazu T, Hirschey MD, Newman J, et al. Suppression of oxidative stress by beta-hydroxybutyrate, an endogenous histone deacetylase inhibitor. Science 2013; 339: 211-4.

https://doi.org/10.1126/science.1227166

34. Kaplan A, Abidi E, El-Yazbi A, et al. Direct cardiovascular impact of SGLT2 inhibitors: Mechanisms and effects. Heart Fail Rev 2018; 23: 419-437. https://doi.org/10.1007/s10741-017-9665-9

35. Frier BM, Schernthaner G, Heller SR. Hypoglycemia and cardiovascular risks. Diabetes Care 2011; 34: S132-7.

https://doi.org/10.2337/dc11-s220

36. Huang $\mathrm{H}$, Huang $\mathrm{B}$, Li Y, et al. Uric acid and risk of heart failure: a systematic review and meta-analysis. Eur J Heart Fail 2014; 16 :
15-24. https://doi.org/10.1093/eurjhf/hft132

37. Baartscheer A, Schumacher CA, Wust RC, et al. Empagliflozin decreases myocardial cytoplasmic $\mathrm{Na}(+)$ through inhibition of the cardiac $\mathrm{Na}(+) / \mathrm{H}(+)$ exchanger in rats and rabbits. Diabetologia 2017 60:568-73. https://doi.org/10.1007/s00125-016-4134-x

38. Byrne NJ, Parajuli N, Levasseur JL, et al. Empagliflozin prevents worsening of cardiac function in an experimental model of pressure overload-induced heart failure. JACC: Basic to Translational Science 2017; 2: 347-54. https://doi.org/10.1016/j.jacbts.2017.07.003

39. Hammoudi N, Jeong D, Singh $\mathrm{R}$, et al. Empagliflozin improves left ventricular diastolic dysfunction in a genetic model of type 2 diabetes. Cardiovasc Drugs Ther 2017; 31: 233-46. https://doi.org/10.1007/s10557-017-6734-1

40. Yanagida A, Iwaisako K, Hatano E, et al. Downregulation of the Wnt-antagonist Dkk2 links the loss of Sept4 and myofibroblastic transformation of hepatic stellate cells. Biochim Biophys Acta 2011; 1812; 1403-1411. https://doi.org/10.1016/j.bbadis.2011.06.015

41. Sano M. Hemodynamic effects of sodium-glucose cotransporter 2 inhibitors. J Clin Med Res 2017; 9: 457-460. 10.14740/jocmr3011w 42. Sano M. Chen S. Imazeki H, et al. Changes in heart rate in patients with type 2 diabetes mellitus after treatment with luseogliflozin: Sub-analysis of placebo controlled, double-blind clinical trials. J Diabetes Investig 2018. https://doi.org/10.1111/jdi.12726

43. Asada N. Takase M. Nakamura J. et al. Dysfunction of fibroblasts of extrarenal origin underlies renal fibrosis and renal anemia in mice. J Clin Invest 2011; 121: 3981-3990. https://doi.org/10.1172/JCI57301 44. Cotter DG, Schugar RC, Crawford PA. Ketone body metabolism and cardiovascular disease. Am J Physiol Heart Circ Physiol 2013; 304: H1060-76. https://doi.org/10.1152/ajpheart.00646.2012

45. Darmellah A, Baetz D, Prunier F, et al. Enhanced activity of the myocardial $\mathrm{Na}^{+} / \mathrm{H}^{+}$exchanger contributes to left ventricular hypertrophy in the GotoKakizaki rat model of type 2 diabetes: critical role of Akt. Diabetologia 2007; 50: 1335-44. https://doi.org/10.1007/s00125-007-0628-x 46. Tahara A, Kurosaki E, Yokono M, et al. Effects of SGLT2 selective inhibitor ipragliflozin on hyperglycemia, hyperlipidemia, hepatic steatosis, oxidative stress, inflammation, and obesity in type 2 diabetic mice. Eur J Pharmacol 2013; 715; 246-255.

https://doi.org/10.1016/j.ejphar.2013.05.014

47. Salim HM, Fukuda D, Yagi S, et al. Glycemic control with ipragliflozin, a novel selective SGLT2 inhibitor, ameliorated endothelial dysfunction in streptozotocin-induced diabetic mouse. Front Cardiovasc Med 2016; 3: 43. https://doi.org/10.3389/fcvm.2016.00043 48. Halimi S, Vergès B. Adverse effects and safety of SGLT-2 inhibitors. Diabetes Metab 2014; 40: S28-S34. https://doi.org/10.1016/S1262-3636(14)72693-X 49. Scheen AJ. SGLT2 inhibition during the COVID-19 epidemic: Friend or Foe? Diabet Metab 2020 https://doi.org/10.1016/j.diabet.2020.06.003 